\title{
Reflections and Constructions on the Forming of New Party Construction Mode of College Student Associations in the New Era Cheng yan
}

\author{
JingDeZhen University
}

Keywords: colleges and universities student associations party construction mode innovation

\begin{abstract}
The scale expanding of colleges and universities brings enlarged enrollments and strengthened student associations. To solve problems exit in the present party construction of college student associations such as insufficient ideological cognition, imperfect system construction and the lack of guiding strength, this essay proposes methods to the new mode construction of the party construction of college associations in the new era. This means that we need to accelerate the pace of the combination of the party construction and student associations, construct a long-term guarantee mechanism, promote the work of party construction with social activities and strengthen the cultivation and education on party members. All of these methods would help strengthen the party construction work in college student associations, perfect the student party construction system, optimize the management mechanism in the college associations, cultivate advanced community culture and enhance the effectiveness of ideological and political education on college students to continuously promote the development of the party construction work and student associations.
\end{abstract}

\section{Status quo of party construction work in China's college student associations}

China accelerated the structure of college infrastructure and enlarged the enrollment scale after the boom of Asian financial crisis in 1997 to positively stimulate the domestic demand and thus began China's college expansion.

In this background of college expansion, China's school age population are having growing demands on higher education, which transform gradually from elite education to mass education. The enrollment scales of colleges, which experience leap development, greatly relieve the economic pressure caused by insufficient domestic demands.

The scale variation trends of China's college students over the years are shown in Chart1.

From the statistics, it is not difficult to find that China's colleges had been expanding too fast since 1998. During the six years from 1999 to 2005, the number of China's college students grew rapidly in a rate of $24.5 \%$ per year and this enlarged enrollment scale directly caused the problems such as backward education quality far behind the expansion speed, the loss of teaching quality and the mismanagement on students.

While colleges slowed down their expansion knowing those disadvantages, the overall scale of college students from 1999 to 2014 had expanded 7.57 times, an average annual expansion of nearly $14 \%$. The student number in regular and junior colleges had the most obvious increase from $3,409,000$ in 1998 to 25,477,000 in 2014, nearly 7.47 times.

The number of postgraduates in 2014 had increased by 9.3 times compared with 1998, growing from 198,885 to $1,848,000$. Meanwhile, unlike the slowed down increase of undergraduates, the number of postgraduates still has an accelerating increasing speed and an obvious expansion.

The number of student associations has increased a lot with the rapid expansion of college enrollment scale. According to incomplete statistics, there are now more than 10,000 student associations with members ranging from ten to thousands in China's colleges, and more than 5,000 are in Beijing. 


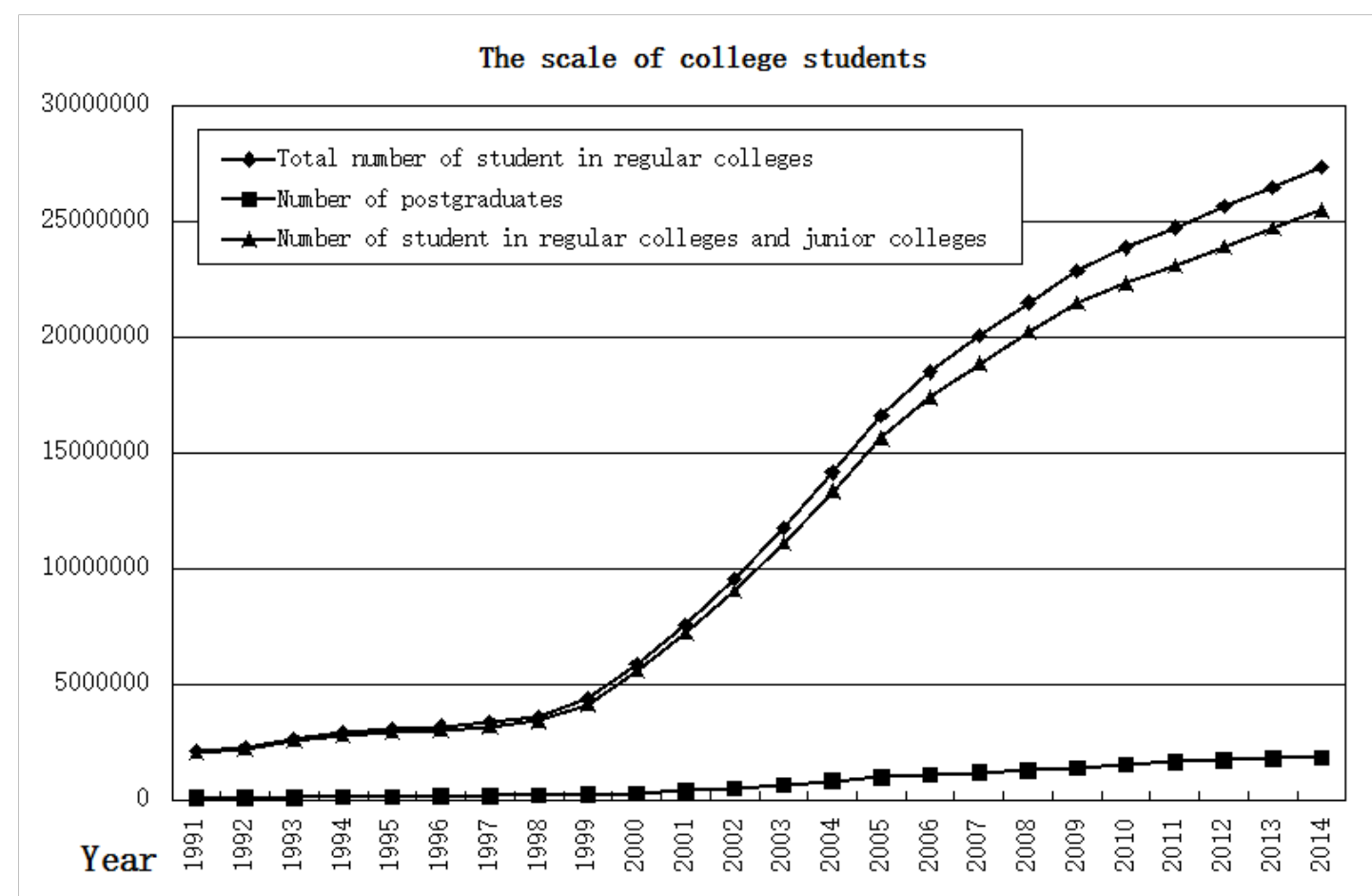

Chart 1 Variation trend of China's college students over the years

Due to the limited teaching source, even part of the college associations have teachers as nominal consultant or minor leader, they rarely take part in actual management. Leading by student cadres, most associations are loosely organized, they lack sustainable development abilities and sufficient influence power. This is just the present situation of China's student associations.

The present situation results the great difficulty in carrying out the work of party construction, the mode of which fails to meet the demands of ideological and political education on college students in the new era and thus need an in-depth mode transformation.

\section{Problems in the party construction work of college student associations in China}

The management layers of China's colleges generally fail to have comprehensive recognition on the function of student associations and lack management theories and practical experiences. For colleges, the management of student associations still focuses on the associations' development and management; these are questions that need research and thinking.

Colleges and universities should treat every student association evenly, however small the association is, it need care and effective guidance from the school. Moreover, schools should have in-depth thinking on how to meet students' development demands in building more associations to enrich the students' after-class life which would help cultivate a complete personality.

The actual problems faced by student associations are how to scientifically orient the association, how to cultivate a core management group, how to enhance the impact of the association, how to improve the quality of its activities and how to realize its continuous development etc.

Therefore, either in the perspective of school or student group, a solid core management group with right thinking orientation is inevitably needed to enhance the cohesion and attraction of the association. While party branches in student associations can help solve problems such as insufficient cohesion, other problems still exit during the process of theory studying and practicing in party constructing work in student associations.

First is the insufficient ideological cognition. The college party construction work goes deep into student associations and should direct the political orientation to provide a significant guarantee of ideology and organization for the healthy development of college associations.

However, in the real working process of party construction in student associations, its importance and urgency failed to get enough attention. The management layer, fail to have a comprehensive recognition on the function of the party construction work in student associations, 
stick to the conventional thinking mode to define the work in the new era, thus causing the gap between party construction and association management.

Party construction work in college student associations is a significant part of the whole college party constructing. The traditional class league party construction work, usually with a fixed schedule, is relatively mature in activity designing and party member development and cultivation. This traditional mode is characterized with solid foundation and is strongly stereotyped.

As a new working model of party construction, however, the present college student association party construction is still in the exploration stage and is strange to the promoting pace of the whole work, requirements of organization and the cooperation of talents cultivation etc. The school management layer's failing to have a comprehensive cognition on the community party construction directly influenced the development of the construction.

Second is the incomplete system construction. College party construction work has its political nature and educational purpose which should convey the party's principles, routes and policies to the educational objects.

Mastering and deeply understanding the logic of college students' thinking and behaviors require the effective combination of ideological and political propaganda and education with servicing and guiding students to further unit them together forming the power for career developing.

While ideological and political education is characterized by seriousness and normalization, college student associations are organized by students spontaneously with little limitation on their members, who can join and leave any association under no pressure, and they take part in different kinds of activities on their own accord or interest.

Therefore for student associations, when concerning the organization form, community members and activity themes, they can all be describe as loose structured. Incongruities exit between the college party construction work and student associations in different aspects such as exiting form, pursuing goals and developing process.

Thus in this imperfect party branch system construction, the theoretical puzzle faced by the college student association party construction is how to integrate the work with student associations.

Third is the weak guidance strength. Surveys on the exploration of current student association party construction work reveal that there are organization structure conflicts exit between the party branches in student associations and the party branches in institutions and departments.

As a new working pattern of party organization, party member cultivation and activity arrangement all need teachers' engaging in the work promotion and activity organization. However in reality, exiting party organizations in colleges can hardly transfer enough members to help promote the party construction work in student associations, which ask for guidance in party branch application, work advancing, theory learning organizing and planning. Attention should be paid to the party construction work in student associations by the management layer and the school's party branch.

Though facing problems of insufficient ideological cognition, imperfect mechanism construction and weak guidance strength, party branch construction in student associations can enhance their future cohesion and has practical significance to the associations' flourish and decline. Only with vigorous vitality and influence, can associations truly realize the coordinance of social function and individual function and therefore implement the human-oriented development concept.

With the development of college student association management, the improving realization on the work, and the enlarging number of the party organization members and instructors, the effective exertion of the function of the party construction is predicable. Party construction in student associations, a newly born position for practicing college party construction, would truly become the effective method promoting the comprehensive and harmonious development of college students.

\section{Developing a new mode for college student association party construction in the new era}

Penetrating in student associations, the essence of college party construction work is to direct the political orientation and to provide an important ideological and organizational guarantee for the 
associations' healthy development.

College party construction work, at a deep layer, is meant to enhance the cohesion and attraction of student associations to keep its vigorous vitality with the help of the party organization as battle fortress so as to realize the long-term healthy development.

The solid party construction work in college student associations is significant to the perfection of college party construction system, optimization of community management mechanism, cultivation of advanced community culture and the elevation of the college students' ideological and political education effects. Therefore, this essay proposes methods developing the new mode for college student association party construction in the new era.

First is to accelerate the integration of the party construction work with student associations. One thing is to integrate the party construction in the regular organization mechanism. Relying on the organization platform of student association, party branch in it would promote the organic integration of party organization with student community. This resultant force would help party organizations in student associations become the effective extension of party construction driving league construction.

The other thing is that party construction work should integrate in the backbone cultivating education. Emphasizing the role played by student party members to highlight their advancement nature and to cultivate a more enthusiastic, more motivated and more serious working attitude. Peer education would also promote the integration of party construction with student association working.

The last thing is to integrate the party construction work in the association member reviewing and recommending. Talents cultivating is the common goal of party construction and community working.

Strengthening the linkage between the party and community members through party branches in student associations to unit and guide them better developing the regular work would incorporate the party's function of cultivating people into the community's developing.

In real practice, party branches in student associations can check the comprehensive performance of the members in daily learning, living and working. Members in student associations who have excellent performance would get recommendations joining the party under the unified arrangement from the general party branch. A good educating atmosphere of enterprising, active learning and surpassing the advanced would be formed in the student associations.

The second thing is to build a long-term guarantee mechanism which would be an important promise for student association party branch. As members of college student associations come from different majors, it is necessary to build long-term mechanism according to the basic requirements from party branch construction and the community's characters. Party branch secretary should be the director or appointed teacher while student party members being the committee of party branch.

Meanwhile, a complete recommendation system needs to be built. Members with good performance both in community and in classes can be considered training in party school and joining party.

Moreover, responsibilities of party members in student associations should be regulated. Systems made to regulate the behaviors of party members and party activists can help play their exemplary vanguard role.

The higher party organization of the community party branch should be clear according to the different situations in different colleges. Based on the student management department or league, the higher party organization should organize, direct, supervise and regulate the activities in community party branches to enforce the management and direction to student association party construction work.

The third thing is to promote the development of party construction work. Building an activity carrier would be the exerting point for the work development in student associations, since the purpose of student associations is to aggregate students with common interests to host different kinds of community activities in the perspective of showing the spirits of contemporary college 
students, enriching the campus cultural life and better understanding how to serve the society.

Party branches in the student associations should make full use of the party members' unity and take them as battle fortress in the community activities to promote the joint and harmonious development of the community members.

Integrating resources both in and out of campus, party branches in student associations should build new carriers and new platforms for party branch activities. These new carriers and platforms should cover and be recommended to all the community members, who would feel the concern from the party organizations.

The last thing is to strengthen party member cultivation and education. Strengthening party member cultivation is the stay point of student association party construction as the final stay point of student community is to educate people.

Improving the comprehensive quality of young students with community activities to cultivate liable successors and qualified constructors for socialist cause, the starting and staying point of student community are to better cultivate college students with comprehensive harmonious development.

As the supplement of the conventional student party branch, the student association party branch should for one thing strengthen the education on ideal and belief and improve the theoretical level, for another thing enforce the evaluation, cultivation and recommendation work on party activists and party members. Evaluation from the student association party branch should be important reference to the inner appraisal, probationary party members become full members and the recommendation for party activists.

We can then strengthen the party construction work in college student associations, perfect the student party constructions system, optimize college student association management mechanism, cultivate advanced community culture and improve the effectiveness of the ideological and political education on college students to further promote the continuous development of party construction and student association.

\section{References}

[1]Yingzi Liu. Study on the College Student Association Party Construction Based on Identity Theory[D].Hunan Agriculture University, 2010.

[2] Xiaodong Liu, Junjie Dong. Exploration and Practice on College Student Association Party Construction Work: Beijing Science and Technology University as Example[J].Research on Ideological Education, 2014, 05:75-78.

[3] Junhua Ruan, Liyong Shen, Fangfang Jin. Investigations and Reflections on College Student Association Party Construction Work [J].Journal of China Youth College for Political Sciences, 2008, 01:42-44.

[4] Xia Zhang, Liuzhu Han. Reflections on Student Association Party Construction Work [J]. College Party Construction and Ideological Education, 2010, 21:22-23.

[5]Fen Wang. Reflections on the College Student Association Party Construction Work in Medical Colleges[J]. Journal of Yangzhou University(higher education research edition), 2012, 02:92-96.

[6]Annexure-IV. Fellows of the Academy in December 2013[A]. Sixty Years of Pakistan Academy of Sciences (1953-2013) Milestones and Salient Activities[C]. 2014.

[7]Yunfei Li, Wen Yan. Several Thoughts on Class Management Work of College Students[A]. Proceedings of 2014 International Conference on Economic Management and Social Science[C]. 2014. 